\title{
Increased epithelial thickness and reduced HIV receptor expression in the ectocervical mucosa is associated with relative HIV resistance
}

\author{
K Broliden*, J Kimani, B Ball, J Cheruiyot, N Mugo, W Jaoko, F Plummer, R Kaul, T Hirbod \\ From AIDS Vaccine 2012 \\ Boston, MA, USA. 9-12 September 2012
}

\section{Background}

The female genital tract is an important site of HIV acquisition, but the epithelial and submucosal tissue factors associated with HIV susceptibility have not been defined.

\section{Methods}

Ectocervical biopsies were obtained from HIV-exposed seronegative $(\mathrm{HESN})$ women $(\mathrm{n}=20)$ and HIV-seronegative lower risk controls $(n=20)$. Epithelial thickness and tissue distribution of immunological markers were assessed in situ by immunohistochemistry and measurement of mRNA expression was performed by quantitative PCR.

\section{Results}

The thickness of the ectocervical epithelium was significantly higher in HESN vs. lower risk subjects. CD4 and DC-SIGN mRNA expression was significantly lower in HESN than lower risk women, and in situ immunohistochemical analysis confirmed the reduced CD4 expression in HESN participants. In addition, immunohistochemistry demonstrated lower CCR5 and higher Langerin expression in the HESN subjects.

\section{Conclusion}

A thicker epithelial barrier and altered expression of HIV binding receptors in the ectocervix of HESN women may contribute to protection against HIV transmission.

Published: 13 September 2012

Karolinska Institutet, Stockholm, Sweden
doi:10.1186/1742-4690-9-S2-P190

Cite this article as: Broliden et al:: Increased epithelial thickness and reduced HIV receptor expression in the ectocervical mucosa is associated with relative HIV resistance. Retrovirology 2012 9(Suppl 2):P190.
Submit your next manuscript to BioMed Central and take full advantage of:

- Convenient online submission

- Thorough peer review

- No space constraints or color figure charges

- Immediate publication on acceptance

- Inclusion in PubMed, CAS, Scopus and Google Scholar

- Research which is freely available for redistribution

Submit your manuscript at www.biomedcentral.com/submit
( Biomed Central 